\title{
The Genetics of Drug Hypersensitivity Reactions
}

\author{
Cornejo-García JA ${ }^{1}, 2$, Jurado-Escobar R ${ }^{1}$, Doña I ${ }^{2}$, Perkins JR ${ }^{1}$, Agúndez JA', \\ García-Martín $\mathrm{E}^{3}$, Viguera $\mathrm{E}^{4}$, Blanca-López $\mathrm{N}^{5}$, Canto $\mathrm{G}^{5}$, Blanca $\mathrm{M}^{2}$
}

\author{
${ }^{1}$ Research Laboratory, IBIMA, Regional University Hospital of Malaga, UMA, Malaga, Spain \\ ${ }^{2}$ Allergy Unit, IBIMA, Regional University Hospital of Malaga, UMA, Malaga, Spain \\ ${ }^{3}$ Department of Pharmacology, University of Extremadura, Caceres, Spain \\ ${ }^{4}$ Genetics Unit, Department of Cell Biology, Genetics and Physiology, Faculty of Sciences, Malaga University, \\ Malaga, Spain \\ ${ }^{5}$ Allergy Service, Infanta Leonor University Hospital, Madrid, Spain
}

J Investig Allergol Clin Immunol 2016; Vol. 26(4): 222-232

doi: 10.18176/jiaci.0078

\begin{abstract}
Drug hypersensitivity reactions (DHRs) are a major problem for healthcare systems, regulatory agencies, and the pharmaceutical industry. DHRs are induced by various mechanisms and encompass a heterogeneous set of potentially life-threatening clinical entities. In addition to environmental effects, individual factors play a key role in this intricate puzzle. However, despite commendable efforts in recent years to identify individual predisposing factors, our knowledge of the genetic basis of these reactions remains incomplete. In this manuscript, we summarize current research on the genetics of DHRs, focusing on specific immune-mediated reactions (immediate and nonimmediate) and on pharmacologically mediated reactions (cross-intolerance to nonsteroidal anti-inflammatory drugs). We also provide some thoughts on potential technological approaches that would help us to decipher the molecular mechanisms underlying DHRs. We believe this manuscript will be of interest not only for allergists and basic researchers in the field, but also for clinicians from various areas of expertise who manage these reactions in their clinical practice.
\end{abstract}

Key words: Drug hypersensitivity. Immediate and nonimmediate reactions. Cross-intolerance. Single-nucleotide polymorphisms. Genome-wide association study.

\section{Resumen}

Las reacciones de hipersensibilidad a fármacos (RHFs) son un problema preocupante para los sistemas de salud, las agencias reguladoras y la industria. Además de la diversidad de mecanismos implicados, las RHFs incluyen un conjunto heterogéneo de entidades clínicas que pueden amenazar la vida del paciente. A esta complejidad se añade el hecho de que, además de factores ambientales, en ellas participan factores individuales. A pesar del considerable esfuerzo desarrollado en los últimos años en la identificación de los factores individuales que predisponen a la aparición de estas reacciones, nuestro conocimiento sobre la base genética de las RHFs es todavía limitado. En esta revisión se presentan los datos disponibles sobre la genética de las RHFs, tomando como modelo las reacciones mediadas por mecanismos inmunológicos específicos (anticuerpos lgE y células T, reacciones inmediatas y no inmediatas) así como las mediadas por mecanismos farmacológicos (intolerancia cruzada a anti-inflamatorios no esteroideos). También se destacan las aproximaciones tecnológicas que pueden proporcionar información fundamental sobre los mecanismos moleculares que subyacen en estas reacciones. Creemos que este manuscrito será útil no solo para alergólogos e investigadores básicos en éste área, sino también para otros profesionales de la medicina que pueden encontrarse con este tipo de reacciones en su práctica clínica.

Palabras clave: Hipersensibilidad a fármacos. Reacciones inmediatas y no inmediatas. Intolerancia cruzada. Polimorfismos de un único nucleótido. Estudios de asociación de genoma completo. 


\section{Introduction}

Adverse drug reactions are defined by the World Health Organization as noxious and unintended responses to a drug that occur at doses normally used in man for the prophylaxis, diagnosis, or therapy of disease or for modification of physiological function [1]. These reactions can be dosedependent and predictable (type A) or dose-independent, unpredictable, and idiosyncratic (type B) [2,3]. Type B includes drug hypersensitivity reactions (DHRs), which are a major problem for healthcare systems, regulatory agencies, and the pharmaceutical industry. DHRs can be induced by specific immunological mechanisms (allergic reactions) or pharmacological mechanisms (nonallergic hypersensitivity) [4].

Depending on the time between drug intake and the onset of symptoms, allergic DHRs may be further classified as immediate and nonimmediate. Immediate reactions usually occur within the first hour, are mediated by specific IgE antibodies, and lead to urticaria/angioedema and/or anaphylaxis [5]. Nonimmediate reactions commonly appear 24-48 hours after drug intake, are mediated by $\mathrm{T}$ lymphocytes, and induce a heterogeneous spectrum of clinical entities that range from mild reactions (eg, urticaria and maculopapular exanthema) to severe cutaneous reactions (eg, Stevens-Johnson syndrome/toxic epidermal necrolysis [SJS-TEN] complex) [6]. $\beta$-Lactam antibiotics (BLs) are the main triggers of immediate DHRs [7], whereas nonimmediate reactions can be induced by a variety of drugs, including allopurinol, carbamazepine, and abacavir [6].

Nonsteroidal anti-inflammatory drugs (NSAIDs), the main triggers of DHRs, induce allergic reactions through IgE- and $\mathrm{T}$ cell-mediated mechanisms. However, they mainly induce nonallergic reactions through the release of inflammatory mediators in the absence of specific immune recognition (crossintolerance $[\mathrm{CI}]$ ) $[8,9]$. In fact, these are the most common type of DHRs [10-13]. The underlying mechanism in CI reactions is thought to be linked to inhibition of cyclooxygenase (COX) 1, which shunts arachidonic acid metabolism toward biosynthesis of cysteinyl-leukotrienes (Cys-LTs) (LTE4, LTC4, and LTE4) and leads to a hypersensitivity response in susceptible individuals [14]. The 3 main phenotypes induced by CI to NSAIDs are NSAID-exacerbated respiratory disease (NERD) in patients with underlying chronic airway respiratory disease (asthma and/or rhinosinusitis with or without nasal polyposis), NSAID-exacerbated cutaneous disease (NECD) in patients with a history of chronic spontaneous urticaria, and NSAID-induced urticaria/angioedema (NIUA) in otherwise healthy individuals [15].

Idiosyncratic reactions to drugs are complex responses influenced by both environmental and genetic factors. Despite the huge efforts made to identify individual predisposing factors in recent years, the genetic basis of DHRs remains elusive. The identification of genetic markers linked to DHRs may help to prevent these reactions and to establish the fundamental aspects of personalized medicine. In this manuscript, we summarize current knowledge on the pharmacogenetics of DHRs by focusing on immediate reactions to BLs, nonimmediate reactions (including allopurinol-induced SJS-TEN and carbamazepine and abacavir-induced hypersensitivity), and CI to NSAIDs. We think this review will be of interest not only for allergists and basic researchers in the field, but also for clinicians from areas of expertise that manage these reactions in their clinical practice.

\section{IgE-Mediated DHRs: The Paradigm of Immediate Reactions to B-Lactams}

Most studies on the genetics of IgE-mediated reactions to BLs analyze single-nucleotide polymorphisms (SNPs) on the IL-4/IL-13 axis and related cytokines. However, study populations are usually small, and independent groups for replication purposes were not included [16-18]. In an Italian population of patients with immediate BL allergy, GuéantRodríguez et al [19] found higher serum specific IgE levels in carriers of the minor allele of the promoter polymorphism $-308 \mathrm{G}>\mathrm{A}$ in TNFA. As TNF- $\alpha$ is released from mast cells through an IgE-dependent mechanism and the SNP is part of an extended HLA-A1-B8-DR3-DQ2 haplotype and influences gene expression [20], its association with BL allergy is thought to be based on antigen presentation [19].

In addition to statistically significant associations with SNPs in IL13 (-1055 C>T and R130Q) and in the $\alpha$-chain of the IL-4 receptor (IL4RA I50V and Q551R), the same group also found that the combination of the less frequent allele of the R130Q polymorphism in IL13 with any of the predominant homozygous genotypes of the 3 polymorphisms analyzed in IL4RA (I50V, S478P, and Q551R) led to a more significant association with the risk of BL allergy than any SNP alone [21]. We recently analyzed some of these associations with atopy in a large series of patients with immediate reactions to BLs [22] and found that total IgE was affected by the Q551R polymorphism and by the $I L 13 \mathrm{RQ} / \mathrm{QQ}$ and $I L 4 R 551 \mathrm{QQ}$ epistatic genotypes [22]. Furthermore, we found statistically significant differences between specific $\operatorname{IgE}$ antibodies to prevalent allergens and the polymorphisms I50V in $I L 4 R$ and $1523 \mathrm{~A}>\mathrm{G}$ in $L A C T B(21) .1523 \mathrm{~A}>\mathrm{G}$ was also associated with specific IgE against BLs [22].

Two SNPs of the nucleotide-binding oligomerization domain 2 gene (NOD2), which is associated with allergic diseases and inflammation [23], modified the risk of immediate reactions to BLs in 2 independent populations from Italy and Spain [24].

Data from the first published genome-wide association study (GWAS) in immediate BL allergy highlighted the influence of variants of the class II MHC HLA-DRA gene and the $C 5$ gene in Spanish and Italian populations [25]. The authors found statistically significant associations between the $H L A-D R A$ SNPs rs7192 and rs8084 and skin test positivity to amoxicillin and penicillins. We suggest that these variants can regulate the presentation of BL-derived antigenic motifs through 3 -dimensional changes in the MHC $\alpha / \beta$ chains [25]. Two SNPs in the HLA-DRA/HLA-DRB5 region (rs7754768 and rs9268832) also underwent multiple comparison adjustments [25]. Our results are consistent with studies linking specific HLA alleles with increased levels of $\operatorname{IgE}[26,27]$ and with the potential effect of NOD2 variants on HLA-DRA expression through the nuclear factor $\kappa \mathrm{B}(\mathrm{NF}-\kappa \mathrm{B})$ pathway $[28,29]$. 
The missense polymorphism rs17612 in the $C 5$ gene was another predictor of immediate BL allergy in the Spanish population and, to a much lesser extent, in the Italian population [25]. Finally, the rs4958427 variant in ZNF300 was also associated with immediate BL allergy in Spain, but not in Italy. Together with NOD1 and NOD2, this gene was strongly associated with inflammation in Crohn disease [30]. ZNF300 encodes a zinc finger protein that binds to the promoter region of genes that enhance the NF- $\kappa \mathrm{B}$ signalling pathway [31] and could affect $H L A-D R A$ expression.

The participation of IgE and the IL-4/IL-13 axis in immediate reactions to BLs is also supported by the association with the rs 11125 polymorphism in galectin-3, a secretory $\beta$-galactoside-binding lectin, which interacts with $\operatorname{IgE}$ and FceRI on the surface of mast cells and B lymphocytes and influences the release of mediators from IgE-sensitized mast cells and T cells [32]. These data, which were obtained in 2 European populations, show that this SNP is the strongest genetic predictor of BL allergy reported to date [32].

\section{Nonimmediate DHRs: T-Cell Effector Responses}

Although various drugs can trigger nonimmediate DHRs and clinical pictures are heterogeneous, we focus on the pharmacogenetics of SJS-TEN induced by allopurinol and carbamazepine and on DHRs induced by abacavir.

\section{Allopurinol-Induced SJS-TEN}

SJS-TEN is a life-threatening mucocutaneous DHR that usually appears 1-3 weeks after drug intake and in which massive keratinocyte apoptosis leads to epidermal detachment $[33,34]$. The mortality rate is close to $30 \%$, ranging from $10 \%$ to $15 \%$ for SJS and from $40 \%$ to $50 \%$ for TEN $[35,36]$. Most significant associations in the genetics of SJS-TEN have been found with alleles of the HLA system.

Allopurinol, an inhibitor of xanthine oxidase commonly used for the management of gout and hyperuricemia, is the drug most frequently involved in SJS-TEN [33,34,37]. The first report of a strong association between allopurinolinduced SJS-TEN and HLA-B*5801 was published in 2005 in Han Chinese living in Taiwan [38]. Although the strength of association is variable, studies point to the robust influence of the HLA-B*5801 allele in allopurinol-induced SJS-TEN in various populations [39-42]. Interestingly, this allele is a risk factor not only for SJS-TEN, but also for other severe and mild cutaneous DHRs in the Han Chinese population [43].

The cost-effectiveness of pharmacogenetic HLA-B*5801 testing before administration of allopurinol has been assessed in various studies. Allopurinol treatment based on the results of HLA-B*5801 genotyping was shown to be less costly and more effective than treatment without genotyping in Korea and could considerably reduce the occurrence of allopurinolinduced DHRs and related deaths [44]. Prospective screening of the HLA-B*5801 allele has also been shown to reduce the incidence of allopurinol-induced DHRs in Thailand [45] and Taiwan [46]. The Clinical Pharmacogenetics Implementation
Consortium guideline for HLA-B genotyping and allopurinol dosing originally published in 2013 [47] has recently been updated [48]. However, in addition to being expensive, HLA-B*5801 testing is time-consuming, and few laboratories have the facilities to perform it. The results of a recent GWAS showed that 21 SNPs on chromosome 6 were significantly associated with allopurinol-induced SJS-TEN in Japanese patients [49]. One of these SNPs is rs9263726 in the psoriasis susceptibility 1 candidate 1 gene, which is in perfect linkage disequilibrium with the HLA-B*5801 allele [50]. This surrogate biomarker is easily identified through a recently developed rapid and inexpensive assay that facilitates prescreening for HLA-B*5801 in this population [50].

\section{Carbamazepine-Induced SJS-TEN}

One of the first studies demonstrating a strong association between a genetic marker, the HLA-B*1502 allele, and carbamazepine-induced SJS-TEN was performed in Han Chinese in 2004 [51] and has been further replicated by other studies performed in the same ethnic group [52,53] and in other Asian populations [54-57], but not in Japanese [58,59] or Europeans $[60,61]$. In contrast to the association between the HLA-B*5801 allele and allopurinol-induced SJSTEN in various populations [41], the association between carbamazepine-induced SJS-TEN and HLA-B*1502 appears to be ethnicity-specific and has led the United States Food and Drug Administration to recommend screening for this allele in patients of Asian descent before initiating carbamazepine [62-64]. Thus, HLA-B*1502 is not only a genetic marker for carbamazepine-induced SJS-TEN but also participates in its pathogenesis. A key role has been proposed for T-cell receptors [65]. Carbamazepine interacts directly with HLA-B*1502 without cellular metabolism and antigen processing, through a mechanism involving the interaction between T-cell receptors and 3 residues (Asn63, Ile95, and Leu156) in the peptide-binding groove of HLA-B*1502 [66].

\section{Abacavir-Induced Hypersensitivity}

Abacavir is a reverse-transcriptase inhibitor used to treat HIV-1 infection. However, 5\%-8\% of patients develop DHRs within the first 2-6 weeks of treatment [67]. The first associations between abacavir-induced DHRs and the HLA-B*5701 allele were reported in Australia and North America in $2002[68,69]$ and shortly after in the United Kingdom [70]. A recent systematic review and meta-analysis analyzed the association between HLA-B*5701 and abacavir hypersensitivity [71]. The authors found that carriage of HLA-B*5701 was significantly associated with abacavir hypersensitivity in whites, blacks, and Hispanics. However, they emphasized the need for rigorous criteria when diagnosing these reactions and highlighted the importance of genetic screening.

Some studies have shown that HLA-B*5701 genotyping is cost-effective and can reduce the incidence of hypersensitivity to abacavir [72,73]. In fact, HLA-B*5701 screening before therapy with abacavir has been recommended in some populations [74-77]. 


\section{Cross-Intolerance to NSAIDs}

The role of genetics in this type of DHRs is supported by the finding that $6 \%$ of patients have a family history of NSAIDinduced reactions [78]. In addition, in 2014, Caimmi et al [79] reported a case of homozygous twins with hypersentivity reaction to NSAIDs. Although NIUA aggregates in families inheriting the minor allele of the $-444 \mathrm{~A}>\mathrm{C}$ polymorphism in the leukotriene $\mathrm{C} 4$ synthase gene ( $L T C 4 S$ ), segregation did not follow a clear Mendelian pattern [80].

Despite growing interest in the genetics of NIUA [81-84], most available data are on NERD $[85,86]$. However, many studies have included limited numbers of individuals, often without replication, and largely in populations of Asian descent [85-87].

Most genetic association studies have focused on polymorphisms in genes from the arachidonic acid pathway (candidate gene approach). However, given the role of this biogenic amine, variants in histamine homeostasis genes may also play a role in NSAID-induced DHRs $[9,88]$. The $939 \mathrm{~A}>\mathrm{G}$ polymorphism in the histamine $\mathrm{N}$-methyltransferase gene (HNMT) has been associated with NECD [89]. A recent study from our group did not reveal associations between common variants in 3 histamine receptors and NSAIDinduced hypersensitivity [90]. Nevertheless, the missense polymorphism rs10156191 (Thr16Met) in diamine oxidase, which causes impaired metabolism of circulating histamine, was associated with NIUA, NERD, and a mixed reaction pattern [91]. Other genetic associations in NSAID-induced DHRs have been found with polymorphisms in the adenosine receptor $\mathrm{A} 3$ gene $(A D O R A 3)(-1050 \mathrm{G}>\mathrm{T}$ and $-564 \mathrm{C}>\mathrm{T}), \mathrm{IL} 4$ $(-589 \mathrm{~T}>\mathrm{C})$ [90], IL13 $(-1111 \mathrm{C}>\mathrm{T})$, and HLA [92-96]. We analyzed 9 SNPs in 5 genes involved in mast cell activation in NIUA and found statistically significant differences when patients were stratified according to clinical symptoms [97]. Genetic variants in the enzymes involved in the metabolism of NSAIDs can also have a role in some types of NSAID-induced DHRs [98]. Additional information concerning the genetics of hypersensitivity to NSAIDs has recently been published [99].

To date, only 3 GWAS on NSAID-induced hypersensitivity have been performed, thus limiting the identification of other potential mechanisms [100-102].

\section{Arachidonic Acid Pathway}

The minor allele frequency (MAF) of the $-444 \mathrm{~A}>\mathrm{C}$ polymorphism (rs730012) in LTC4S has been reported to be higher in patients with NERD than in aspirin-tolerant asthmatics and healthy individuals [103]. NERD patients have also shown increased LTC4S mRNA in bronchial biopsies $[104,105]$. However, the association between NERD and rs730012 was not replicated in American patients [106] or in Asian patients $[107,108]$. In a group of Polish NECD patients, the MAF of rs 730012 was also higher [109], but not in Spanish patients with NSAID-induced angioedema [110]. We did not find any association between the polymorphism $-444 \mathrm{~A}>\mathrm{C}$ in LTC4S and NIUA in a study that included the largest number of Spanish patients published to date [81]. The rs5789 and rs 10306135 mutations in the prostaglandin endoperoxidase synthase gene (PTGS-1) (COX-1) were recently found to be associated with NERD [111].
A specific haplotype in the promoter region of the arachidonate 5-lipoxygenase gene ( $A L O X 5)$ was very frequent in Korean NERD patients [108]. However, no evidence was found for the rs 1132340 polymorphism in ALOX5 activating protein, which we found in NIUA patients [81]. Another study in Spanish NIUA patients did not reveal significant associations with the rs 4948672 polymorphism in ALOX5 after multiple testing correction [82]. We found a significant association between the rs 7220870 polymorphism in $A L O X 15(-272 \mathrm{C}>\mathrm{A})$ and NIUA in 2 independent Spanish populations [81], although different results were obtained in Korea [112]. We also recently found that the rs 3892408 polymorphism in $A L O X 15$ was associated with NERD in Spain [111].

Vidal et al [82] reported the first identification of a TBXAS1 polymorphism (rs6962291) in NIUA patients [82]. The protective role of this SNP was also reported in NERD [113].

Arachidonic acid pathway receptors may also have a role in NSAID-induced DHRs [114], and significant associations were found between NERD and the prostaglandin receptor genes PGERI-4 and PGGIR [115,116]. We also found associations between NIUA and 2 SNPs in PGE1R (rs3810253 and rs3810255) and rs1254598 in PGER2 [81]; no such association was found in East Asian NERD patients [115]. A recent study found the MAF of PTGER4 -1254G>A to be higher in NECD patients than in controls [117]. A polymorphism in $P G D R$ (rs8004654) was shown to be significantly associated with NIUA in 2 independent Spanish populations [81] and in an American asthma study [118].

Three SNPs in the promoter region of the Cys-LT receptor 1 gene $($ CYSLTR 1$)(-634 \mathrm{C}>\mathrm{T},-475 \mathrm{~A}>\mathrm{C}$, and $-336 \mathrm{~A}>\mathrm{G})$ have been associated with NERD [119]. We also found a synonymous SNP in CYSLTR1 (rs320995) to be associated with NIUA [81]. This polymorphism has been inconsistently associated with NERD and asthma and lung function in various studies [119-122], as well as with urinary LTE4 in asthmatics [123]. Interestingly, rs320995 is in strong linkage disequilibrium with the promoter polymorphisms analyzed by Kim et al [119], which affect gene transcription. SNPs that affect the expression of CYSLTR 2 have been associated with NERD [124]. However, no SNPs in CYSLTR2 have been found to be associated with NIUA [81].

Palikhe et al [125] recently reported a significant association between the $-4684 \mathrm{~T}>\mathrm{C}$ polymorphism on the promoter of the TBXA2 receptor gene (TBXA2R) and NIUA, although they did not find an association with NECD [125]. Associations have not been found for other SNPs in TXBA2R in Spain [82]. Finally, the MAF of TBXA2R $+795 \mathrm{~T}>\mathrm{C}$ was higher in NERD than in aspirin-tolerant asthmatics [126].

\section{GWAS Approach}

GWAS can identify new genes and pathways involved in common complex diseases, although few studies on NSAIDinduced DHRs have been performed. The first GWAS was performed in a Korean population of NERD patients [100]. The most significant associations were found for SNPs in a 68-kDa centrosomal protein (CEP68), and the nonsynonymous polymorphism rs7572857 (Gly74Ser) was associated with the decline in $\mathrm{FEV}_{1}[100]$. We recently analyzed 53 common CEP68 variants in a Spanish population of patients with 
NSAID-induced DHRs including NIUA, NERD, and blended reactions [83]. Seventeen SNPs, including the Gly74Ser variant, were associated with NIUA. Although not remaining significant after multiple testing corrections, 8 of these variants were also associated with NERD and blended reactions [83]. These results suggest that CEP68 variants may play a key role in the development of various manifestations of NSAIDinduced hypersensitivity.

In another GWAS, the most significant association with susceptibility to NERD was found for the polymorphism rs1042151 in HLA-DPB1 (Met105Val) [101]. More recently, another polymorphism in $H L A-D P B 1$ (rs3128965), which is in perfect linkage disequilibrium with rs1042151, has been associated with NERD in Koreans [127].

We recently conducted a GWAS of both Spanish and Han Chinese NIUA patients [102] and obtained suggestive associations for 3 clusters in the Spanish population (RIMS1, $B I C C 1$, and $R A D 51 L 1)$ and 1 region in the Han Chinese population $(A B I 3 B P)$. Most of these regions are related to $\mathrm{Ca}_{2}^{+}$, cAMP, and/or P53 signaling pathways [102].

\section{Further Approaches for Deciphering DHRs}

Monitoring the acute phase of DHRs through analysis of activation status and cell populations using flow cytometry techniques, immunohistochemistry, and transcriptomic assays of gene expression has proven to be a useful approach for better classifying and understanding these reactions [128-132].

In addition to candidate gene and GWAS approaches, high-throughput technologies can be used to unravel the mechanisms involved in DHRs, including epigenetic mechanisms and gene expression. Deep sequencing studies can also be performed. In this sense, a recent genome-wide methylation study on nasal polyps found a differential pattern in patients with NSAID-induced DHRs [133], and a set of 2 gene markers has been proposed to discriminate NERD from aspirin-tolerant asthma [134]. Exome sequencing has also been used to identify variants associated with hypersensitivity to NSAIDs [135].

In silico studies could prove useful for analyzing how genetic variants affect gene expression in normal and pathologic states. Using this approach we investigated the 5 ' upstream regions of $C O X-1$ and -2 and their influence on transcription factor binding and gene expression [136]. Other SNPs with functional effects can be found in these genes [137], and next-generation sequencing studies in patients with hypersensitivity to NSAIDs are ongoing. Systems biology is a powerful instrument for integrating data from various studies that will shed new light on the mechanisms underlying drug hypersensitivity [130-140].

\section{Funding}

JA Cornejo-García is supported by the Miguel Servet Program (Ref CP14/00034), and JR Perkins by the Sara Borrell Program (Ref CD14/00242) (Carlos III National Health Institute, Spanish Ministry of Economy and Competitiveness). This study was supported by grants from the Carlos III
National Health Institute RD12/0013 (RIRAAF network), FIS PI12/02247, FIS PI13/02598, FISPI15/00726, and PI15/00303; and Junta de Extremadura (Grant GR15026, cofounded by European Regional Development Fund, ERDF), and the Health Government of Andalusia (PI-0279-2012 and PI-0463-2013).

\section{Conflicts of Interest}

The authors declare that they have no conflicts of interest.

\section{References}

1. WHO. International drug monitoring: the role of national centres. Rep Ser WHO. 1972 (498).

2. Rawlins MD TJ. Pathogenesis of adverse drug reactions. In: Davis DM Ed Textbook of adverse drug reactions Oxford University Press: Oxford 1977; 10.

3. Edwards IR, Aronson JK. Adverse drug reactions: definitions, diagnosis, and management. Lancet. 2000 Oct 7;356(9237):1255-9.

4. Johansson SG, Hourihane JO, Bousquet J, Bruijnzeel-Koomen C, Dreborg S, Haahtela T, Kowalski ML, Mygind N, Ring J, van Cauwenberge $P$, van Hage-Hamsten $M$, Wüthrich B. A revised nomenclature for allergy. An EAACl position statement from the EAACI nomenclature task force. Allergy. 2001;56(9):81324.

5. Antunez C, Fernandez T, Blanca-Lopez N, Torres MJ, Mayorga C, Canto G, Fernández J, Moya MC, Blanca M. IgE antibodies to betalactams: relationship between the triggering hapten and the specificity of the immune response. Allergy. 2006;61(8):940-6.

6. Torres MJ, Mayorga C, Blanca M. Nonimmediate allergic reactions induced by drugs: pathogenesis and diagnostic tests. J Investig Allergol Clin Immunol. 2009;19(2):80-90.

7. Blanca M, Romano A, Torres MJ, Fernandez J, Mayorga C, Rodriguez J, Demoly P, Bousquet PJ, Merk HF, Sanz ML, Ott $\mathrm{H}$, Atanasković-Marković M. Update on the evaluation of hypersensitivity reactions to betalactams. Allergy. 2009;64(2):183-93.

8. Canto MG, Andreu I, Fernandez J, Blanca M. Selective immediate hypersensitivity reactions to NSAIDs. Curr Opin Allergy Clin Immunol. 2009;9(4):293-7.

9. Cornejo-Garcia JA, Blanca-Lopez N, Dona I, Andreu I, Agundez JA, Carballo M, Blanca M, Canto MG. Hypersensitivity reactions to non-steroidal anti-inflammatory drugs. Curr Drug Metab. 2009;10(9):971-80.

10. Doña I, Blanca-Lopez N, Cornejo-Garcia JA, Torres MJ, Laguna JJ, Fernandez J, Rosado A, Rondón C, Campo P, Agúndez JA, Blanca M, Canto $\mathrm{G}$. Characteristics of subjects experiencing hypersensitivity to non-steroidal anti-inflammatory drugs: patterns of response. Clin Exp Allergy. 2011;41(1):86-95.

11. Doña I, Blanca-Lopez N, Torres MJ, Garcia-Campos J, GarciaNunez I, Gomez F, Salas M, Rondón C, Canto MG, Blanca M. Drug hypersensitivity reactions: response patterns, drug involved, and temporal variations in a large series of patients. J Investig Allergol Clin Immunol. 2012;22(5):363-71.

12. Doña I, Barrionuevo E, Blanca-Lopez N, Torres MJ, Fernandez TD, Mayorga C, Canto G, Blanca M. Trends in hypersensitivity 
drug reactions: more drugs, more response patterns, more heterogeneity. J Investig Allergol Clin Immunol. 2014;24(3):143-53.

13. Ortega N, Doña I, Moreno E, Audicana MT, Barasona MJ, Berges-Gimeno MP, Blanca-Lopez N, Lobera T, Padial A, Rosado A, Torres MJ. Practical guidelines for diagnosing hypersensitivity reactions to nonsteroidal anti-inflammatory drugs. J Investig Allergol Clin Immunol. 2014;24(5):308-23.

14. Szczeklik A, Sanak M. The broken balance in aspirin hypersensitivity. European journal of pharmacology. 2006;533(1-3):145-55.

15. Kowalski ML, Asero R, Bavbek S, Blanca M, Blanca-Lopez N, Bochenek G, Brockow K, Campo P, Celik G, Cernadas J, Cortellini G, Gomes E, Niżankowska-Mogilnicka E, Romano A, Szczeklik A, Testi S, Torres MJ, Wöhrl S, Makowska J. Classification and practical approach to the diagnosis and management of hypersensitivity to nonsteroidal antiinflammatory drugs. Allergy. 2013;68(10):1219-32.

16. Yang J, Qiao HL, Dong ZM. Polymorphisms of IL-13 and IL4-IL-13-SNPs in patients with penicillin allergies. Eur J Clin Pharmacol. 2005;61(11):803-9.

17. Qiao HL, Wen Q, Gao N, Tian X, Jia LJ. Association of IL-10 level and IL-10 promoter SNPs with specific antibodies in penicillinallergic patients. Eur J Clin Pharmacol. 2007;63(3):263-9.

18. Gao N, Qiao HL, Jia LJ, Tian X, Zhang YW. Relationships between specific serum IgE, IgG, IFN-gamma level and IFNgamma, IFNR1 polymorphisms in patients with penicillin allergy. Eur J Clin Pharmacol. 2008;64(10):971-7.

19. Gueant-Rodriguez RM, Gueant JL, Viola M, Tramoy D, Gaeta F, Romano A. Association of tumor necrosis factoralpha $-308 \mathrm{G}>\mathrm{A}$ polymorphism with IgE-mediated allergy to betalactams in an Italian population. Pharmacogenomics J. 2008;8(2):162-8.

20. Wilson AG, de Vries N, Pociot F, di Giovine FS, van der Putte LB, Duff GW. An allelic polymorphism within the human tumor necrosis factor alpha promoter region is strongly associated with HLA A1, B8, and DR3 alleles. J Exp Med. 1993;177(2):557-60.

21. Gueant-Rodriguez RM, Romano A, Beri-Dexheimer M, Viola M, Gaeta F, Gueant JL. Gene-gene interactions of IL13 and IL4RA variants in immediate allergic reactions to betalactam antibiotics. Pharmacogenet Genomics. 2006;16(10):713-9.

22. Cornejo-Garcia JA, Gueant-Rodriguez RM, Torres MJ, Blanca-Lopez N, Tramoy D, Romano A, Blanca M, Guéant JL. Biological and genetic determinants of atopy are predictors of immediate-type allergy to betalactams, in Spain. Allergy. 2012;67(9):1181-5.

23. Duan W, Mehta AK, Magalhaes JG, Ziegler SF, Dong C, Philpott DJ, Croft M. Innate signals from Nod2 block respiratory tolerance and program $\mathrm{T}(\mathrm{H}) 2$-driven allergic inflammation. J Allergy Clin Immunol. 2010;126(6):1284-93.

24. Bursztejn AC, Romano A, Gueant-Rodriguez RM, Cornejo JA, Oussalah A, Chery C, Gastin I, Gaeta F, Barbaud A, Blanca M, Guéant JL. Allergy to betalactams and nucleotide-binding oligomerization domain (NOD) gene polymorphisms. Allergy. 2013;68(8):1076-80.

25. Gueant JL, Romano A, Cornejo-Garcia JA, Oussalah A, Chery C, Blanca-Lopez N, Guéant-Rodriguez RM, Gaeta F, Rouyer $P$, Josse $T$, Canto G, Carmona FD, Bossini-Castillo L, Martin
J, Laguna JJ, Fernandez J, Feo F, Ostrov DA, Plasencia PC, Mayorga C, Torres MJ, Blanca M. HLA-DRA variants predict penicillin allergy in genome-wide fine-mapping genotyping. J Allergy Clin Immunol. 2015;135(1):253-9.

26. Stephan V, Kuehr J, Seibt A, Saueressig H, Zingsem S, Dinh TD Moseler M, Wahn V, Deichmann KA. Genetic linkage of HLAclass II locus to mite-specific IgE immune responsiveness. Clin Exp Allergy. 1999;29(8):1049-54.

27. Grammatikos AP. The genetic and environmental basis of atopic diseases. Ann Med. 2008;40(7):482-95.

28. Neefjes J, Jongsma ML, Paul P, Bakke O. Towards a systems understanding of $\mathrm{MHC}$ class I and $\mathrm{MHC}$ class II antigen presentation. Nat Rev Immunol. 2011;11(12):823-36.

29. Yang Z, Gu P, Shao X, Li Z, Zhou Y, Lu L, Chou KY. Mutated major histocompatibility complex class II transactivator upregulates interleukin-33-dependent differentiation of Th2 subset through Nod2 binding for NLR (NOD-like receptor) signaling initiation. J Biol Chem. 2012;287(13):9972-81.

30. Parkes M, Barrett JC, Prescott NJ, Tremelling M, Anderson CA, Fisher SA, Roberts RG, Nimmo ER, Cummings FR, Soars D, Drummond $H$, Lees CW, Khawaja SA, Bagnall R, Burke DA, Todhunter CE, Ahmad T, Onnie CM, McArdle W, Strachan D, Bethel G, Bryan C, Lewis CM, Deloukas P, Forbes A, Sanderson J, Jewell DP, Satsangi J, Mansfield JC; Wellcome Trust Case Control Consortium, Cardon L, Mathew CG. Sequence variants in the autophagy gene IRGM and multiple other replicating loci contribute to Crohn's disease susceptibility. Nat Genet. 2007;39(7):830-2.

31. Wang T, Wang XG, Xu JH, Wu XP, Qiu HL, Yi H, Li WX Overexpression of the human ZNF300 gene enhances growth and metastasis of cancer cells through activating NF-kB pathway. J Cell Mol Med. 2012;16(5):1134-45.

32. Cornejo-Garcia JA, Romano A, Gueant-Rodriguez RM Oussalah A, Blanca-Lopez N, Gaeta F, Tramoy D, Josse T, Doña I, Torres MJ, Canto G, Blanca M, Guéant JL. A nonsynonymous polymorphism in galectin-3 lectin domain is associated with allergic reactions to beta-lactam antibiotics. Pharmacogenomics J. 2016;16(1):79-82.

33. Roujeau JC, Kelly JP, Naldi L, Rzany B, Stern RS, Anderson T, Auquier A, Bastuji-Garin S, Correia O, Locati F, Mockenhaupt M, Paoletti C, Shapiro S, Shear N, Schöpf E, Kaufman DW. Medication use and the risk of Stevens-Johnson syndrome or toxic epidermal necrolysis. N Eng J Med. 1995;333(24):1600-7.

34. Diphoorn J, Cazzaniga S, Gamba C, Schroeder J, Citterio A, Rivolta AL, Vighi GD, Naldi L. Incidence, causative factors and mortality rates of Stevens-Johnson syndrome (SJS) and toxic epidermal necrolysis (TEN) in northern Italy: data from the REACT registry. Pharmacoepidemiol Drug Saf. 2016;25(2):196203.

35. Roujeau JC, Bricard G, Nicolas JF. Drug-induced epidermal necrolysis: Important new piece to end the puzzle. J Allergy Clin Immunol. 2011;128(6):1277-8.

36. Heng YK, Lee HY, Roujeau JC. Epidermal necrolysis: 60 years of errors and advances. Br J Dermatol. 2015;173(5):1250-4.

37. Halevy S, Ghislain PD, Mockenhaupt M, Fagot JP, Bouwes Bavinck JN, Sidoroff A, Naldi L, Dunant A, Viboud C, Roujeau $J C$. Allopurinol is the most common cause of Stevens-Johnson syndrome and toxic epidermal necrolysis in Europe and Israel. J Am Acad Dermatol. 2008;58(1):25-32. 
38. Hung SI, Chung WH, Liou LB, Chu CC, Lin M, Huang HP, , Lin YL, Lan JL, Yang LC, Hong HS, Chen MJ, Lai PC, Wu MS, Chu CY, Wang KH, Chen CH, Fann CS, Wu JY, Chen YT. HLA-B * 5801 allele as a genetic marker for severe cutaneous adverse reactions caused by allopurinol. Proc Natl Acad Sci U S A. 2005;102(11):4134-9.

39. Tassaneeyakul $W$, Jantararoungtong $T$, Chen $P$, Lin PY, Tiamkao S, Khunarkornsiri U, Chucherd P, Konyoung P, Vannaprasaht S, Choonhakarn C, Pisuttimarn P, Sangviroon A, Tassaneeyakul W. Strong association between HLA-B ${ }^{\star} 5801$ and allopurinolinduced Stevens-Johnson syndrome and toxic epidermal necrolysis in a Thai population. Pharmacogenet Genomics. 2009;19(9):704-9.

40. Kang HR, Jee $Y K$, Kim YS, Lee $\mathrm{CH}$, Jung JW, Kim SH, Park HW, Chang YS, Jang IJ, Cho SH, Min KU, Kim SH, Lee KW. Positive and negative associations of HLA class I alleles with allopurinol-induced SCARs in Koreans. Pharmacogenet Genomics. 2011;21(5):303-7.

41. Somkrua $R$, Eickman EE, Saokaew S, Lohitnavy $M$, Chaiyakunapruk N. Association of HLA-B*5801 allele and allopurinol-induced Stevens Johnson syndrome and toxic epidermal necrolysis: a systematic review and meta-analysis. BMC Med Genet. 2011;12:118.

42. Goncalo $M$, Coutinho I, Teixeira V, Gameiro AR, Brites MM, Nunes $R$, Martinho A. HLA-B*58:01 is a risk factor for allopurinol-induced DRESS and Stevens-Johnson syndrome/ toxic epidermal necrolysis in a Portuguese population. $\mathrm{Br} \mathrm{J}$ Dermatol. 2013;169(3):660-5.

43. Cao ZH, Wei ZY, Zhu QY, Zhang JY, Yang L, Qin SY, Shao LY, Zhang YT, Xuan JK, Li QL, Xu JH, Xu F, Ma L, Huang HY, Xing QH, Luo XQ. HLA-B* 58:01 allele is associated with augmented risk for both mild and severe cutaneous adverse reactions induced by allopurinol in Han Chinese. Pharmacogenomics. 2012;13(10):1193-201.

44. Park DJ, Kang JH, Lee JW, Lee KE, Wen L, Kim TJ, Park YW, Park SH, Lee SS. Cost-effectiveness analysis of HLA-B5801 genotyping in the treatment of gout patients with chronic renal insufficiency in Korea. Arthritis Care Res (Hoboken). 2015;67(2):280-7.

45. SaokaewS, TassaneeyakulW, Maenthaisong R, Chaiyakunapruk $N$. Cost-effectiveness analysis of $H L A-B * 5801$ testing in preventing allopurinol-induced SJS/TEN in Thai population. Plos one. 2014;9(4):e94294.

46. Ko TM, Tsai CY, Chen SY, Chen KS, Yu KH, Chu CS, Huang CM, Wang CR, Weng CT, Yu CL, Hsieh SC, Tsai JC, Lai WT, Tsai WC, Yin GD, Ou TT, Cheng KH, Yen JH, Liou TL, Lin $\mathrm{TH}$, Chen DY, Hsiao PJ, Weng MY, Chen YM, Chen $\mathrm{CH}_{\text {, }}$ Liu MF, Yen HW, Lee JJ, Kuo MC, Wu CC, Hung SY, Luo SF, Yang YH, Chuang HP, Chou YC, Liao HT, Wang CW, Huang $\mathrm{CL}$, Chang $\mathrm{CS}$, Lee MT, Chen $\mathrm{P}$, Wong $\mathrm{CS}$, Chen $\mathrm{CH}$, Wu JY, Chen YT, Shen CY. Use of HLA-B*58:01 genotyping to prevent allopurinol induced severe cutaneous adverse reactions in Taiwan: national prospective cohort study. BMJ. 2015;351:h4848.

47. Hershfield MS, Callaghan JT, Tassaneeyakul W, Mushiroda T, Thorn CF, Klein TE, Lee MT. Clinical Pharmacogenetics Implementation Consortium guidelines for human leukocyte antigen-B genotype and allopurinol dosing. Clin Pharmacol Ther. 2013;93(2):153-8.
48. Saito Y, Stamp LK, Caudle KE, Hershfield MS, McDonagh EM, Callaghan JT, Tassaneeyakul W, Mushiroda T, Kamatani N, Goldspiel BR, Phillips EJ, Klein TE, Lee MT. Clinical Pharmacogenetics Implementation Consortium (CPIC) guidelines for human leukocyte antigen B (HLA-B) genotype and allopurinol dosing: 2015 update. Clin Pharmacol Ther. 2016;99(1):36-7.

49. Tohkin M, Kaniwa N, Saito Y, Sugiyama E, Kurose $K$, Nishikawa J, Hasegawa R, Aihara M, Matsunaga $K$, Abe M, Furuya $H$, Takahashi Y, Ikeda H, Muramatsu M, Ueta M, Sotozono C, Kinoshita S, Ikezawa Z. A whole-genome association study of major determinants for allopurinol-related Stevens-Johnson syndrome and toxic epidermal necrolysis in Japanese patients. Pharmacogenomics J. 2013;13(1):60-9.

50. Maekawa K, Nishikawa J, Kaniwa N, Sugiyama E, Koizumi T, Kurose K, Tohkin M, Saito Y. Development of a rapid and inexpensive assay for detecting a surrogate genetic polymorphism of HLA-B*58:01: a partially predictive but useful biomarker for allopurinol-related Stevens-Johnson syndrome/toxic epidermal necrolysis in Japanese. Drug Metab Pharmacokinet. 2012;27(4):447-50.

51. Chung WH, Hung SI, Hong HS, Hsih MS, Yang LC, Ho HC, Wu JY, Chen YT. Medical genetics: a marker for Stevens-Johnson syndrome. Nature. 2004;428(6982):486.

52. Hung SI, Chung WH, Jee SH, Chen WC, Chang YT, Lee WR, Hu SL, Wu MT, Chen GS, Wong TW, Hsiao PF, Chen WH, Shih HY, Fang WH, Wei CY, Lou YH, Huang YL, Lin JJ, Chen YT. Genetic susceptibility to carbamazepine-induced cutaneous adverse drug reactions. Pharmacogenet Genomics. 2006;16(4):297306.

53. Man CB, Kwan P, Baum L, Yu E, Lau KM, Cheng AS, Ng MH. Association between HLA-B*1502 allele and antiepileptic drug-induced cutaneous reactions in Han Chinese. Epilepsia. 2007;48(5):1015-8.

54. Locharernkul C, Loplumlert J, Limotai C, Korkij W, Desudchit T, Tongkobpetch S, Kangwanshiratada O, Hirankarn N, Suphapeetiporn K, Shotelersuk V. Carbamazepine and phenytoin induced Stevens-Johnson syndrome is associated with HLA-B*1502 allele in Thai population. Epilepsia. 2008:49(12):2087-91.

55. Hsiao YH, Hui RC, Wu T, Chang WC, Hsih MS, Yang CH, Ho $H C$, Chang YG, Chen MJ, Lin JY, Chen DP, Chang PY, Wu $\mathrm{TL}$, Hung SI, Chung WH. Genotype-phenotype association between HLA and carbamazepine-induced hypersensitivity reactions: strength and clinical correlations. J Dermatol Sci. 2014;73(2):101-9.

56. Aggarwal R, Sharma M, Modi M, Garg VK, Salaria M. HLA-B * 1502 is associated with carbamazepine induced StevensJohnson syndrome in North Indian population. Hum Immunol. 2014;75(11):1120-2.

57. Nguyen DV, Chu HC, Nguyen DV, Phan MH, Craig T, Baumgart K, van Nunen S. HLA-B*1502 and carbamazepine-induced severe cutaneous adverse drug reactions in Vietnamese. Asia Pac Allergy. 2015;5(2):68-77.

58. Kaniwa N, Saito Y, Aihara M, Matsunaga K, Tohkin M, Kurose K, Sawada J, Furuya H, Takahashi Y, Muramatsu M, Kinoshita S, Abe M, Ikeda H, Kashiwagi M, Song $Y$, Ueta M, Sotozono C, Ikezawa Z, Hasegawa R. HLA-B locus in Japanese patients with anti-epileptics and allopurinol-related Stevens-Johnson 
syndrome and toxic epidermal necrolysis. Pharmacogenomics. 2008;9(11):1617-22.

59. Ikeda H, Takahashi Y, Yamazaki E, Fujiwara T, Kaniwa N, Saito Y, Aihara M, Kashiwagi M, Muramatsu M. HLA class I markers in Japanese patients with carbamazepine-induced cutaneous adverse reactions. Epilepsia. 2010;51(2):297-300.

60. Lonjou C, Thomas L, Borot N, Ledger N, de Toma C, LeLouet H, Graf E, Schumacher M, Hovnanian A, Mockenhaupt M, Roujeau JC. A marker for Stevens-Johnson syndrome ...: ethnicity matters. Pharmacogenomics J. 2006;6(4):265-8.

61. Lonjou C, Borot N, Sekula P, Ledger N, Thomas L, Halevy S, Naldi L, Bouwes-Bavinck JN, Sidoroff A, de Toma C, Schumacher M, Roujeau JC, Hovnanian A, Mockenhaupt M. A European study of HLA-B in Stevens-Johnson syndrome and toxic epidermal necrolysis related to five high-risk drugs. Pharmacogenet Genomics. 2008;18(2):99-107.

62. Tangamornsuksan W, Chaiyakunapruk N, Somkrua R, Lohitnavy M, Tassaneeyakul W. Relationship between the HLA-B*1502 allele and carbamazepine-induced Stevens-Johnson syndrome and toxic epidermal necrolysis: a systematic review and metaanalysis. JAMA Dermatol. 2013;149(9):1025-32.

63. Amstutz U, Shear NH, Rieder MJ, Hwang S, Fung V, Nakamura $H$, Connolly MB, Ito $S$, Carleton BC. Recommendations for $H L A-B * 15: 02$ and $H L A-A * 31: 01$ genetic testing to reduce the risk of carbamazepine-induced hypersensitivity reactions. Epilepsia. 2014;55(4):496-506.

64. Ferrell PB, Jr., McLeod HL. Carbamazepine, HLA-B*1502 and risk of Stevens-Johnson syndrome and toxic epidermal necrolysis: US FDA recommendations. Pharmacogenomics. 2008;9(10):1543-6.

65. Ko TM, Chung WH, Wei CY, Shih HY, Chen JK, Lin CH, Chen YT, Hung SI. Shared and restricted T-cell receptor use is crucial for carbamazepine-induced Stevens-Johnson syndrome. J Allergy Clin Immunol. 2011;128(6):1266-76.

66. Wei $C Y$, Chung WH, Huang HW, Chen YT, Hung SI. Direct interaction between HLA-B and carbamazepine activates $T$ cells in patients with Stevens-Johnson syndrome. J Allergy Clin Immunology. 2012;129(6):1562-9.

67. Cutrell AG, Hernandez JE, Fleming JW, Edwards MT, Moore MA, Brothers CH, Scott TR. Updated clinical risk factor analysis of suspected hypersensitivity reactions to abacavir. Ann Pharmacother. 2004;38(12):2171-2.

68. Mallal S, Nolan D, Witt C, Masel G, Martin AM, Moore C, Sayer D, Castley A, Mamotte C, Maxwell D, James I, Christiansen FT. Association between presence of HLA-B *5701, HLA-DR7, and HLA-DQ3 and hypersensitivity to HIV-1 reverse-transcriptase inhibitor abacavir. Lancet. 2002;359(9308):727-32.

69. Hetherington S, Hughes AR, Mosteller M, Shortino D, Baker $\mathrm{KL}$, Spreen W, Lai E, Davies K, Handley A, Dow DJ, Fling ME, Stocum M, Bowman C, Thurmond LM, Roses AD. Genetic variations in $H L A-B$ region and hypersensitivity reactions to abacavir. Lancet. 2002:359(9312):1121-2.

70. Hughes DA, Vilar FJ, Ward CC, Alfirevic A, Park BK, Pirmohamed M. Cost-effectiveness analysis of HLA B*5701 genotyping in preventing abacavir hypersensitivity. Pharmacogenetics. 2004;14(6):335-42.

71. Sousa-Pinto B, Pinto-Ramos J, Correia C, Goncalves-Costa G, Gomes L, Gil-Mata S, Gil-Mata S, Araújo L, Delgado L. Pharmacogenetics of abacavir hypersensitivity: A systematic review and meta-analysis of the association with $H L A-B * 57: 01$. J Allergy Clin Immunology. 2015;136(4):1092-4.

72. Schackman BR, Scott CA, Walensky RP, Losina E, Freedberg KA, Sax PE. The cost-effectiveness of HLA-B*5701 genetic screening to guide initial antiretroviral therapy for HIV. AIDS. 2008;22(15):2025-33.

73. Rauch A, Nolan D, Martin A, McKinnon E, Almeida C, Mallal $S$. Prospective genetic screening decreases the incidence of abacavir hypersensitivity reactions in the Western Australian HIV cohort study. Clin Infect Dis. 2006;43(1):99-102.

74. Mallal S, Phillips E, Carosi G, Molina JM, Workman C, Tomazic J, Jägel-Guedes E, Rugina S, Kozyrev O, Cid JF, Hay P, Nolan D, Hughes $S$, Hughes A, Ryan S, Fitch N, Thorborn D, Benbow A. HLA-B ${ }^{*} 5701$ screening for hypersensitivity to abacavir. N Eng J Med. 2008;358(6):568-79.

75. Zucman D, Truchis P, Majerholc C, Stegman S, Caillat-Zucman S. Prospective screening for human leukocyte antigen- $B^{*} 5701$ avoids abacavir hypersensitivity reaction in the ethnically mixed French HIV population. J Acquir Immune Defic Syndr. 2007;45(1):1-3.

76. Nolan D. HLA-B ${ }^{\star} 5701$ screening prior to abacavir prescription: clinical and laboratory aspects. Crit Rev Clin Lab Sci. 2009;46(3):153-65

77. Agundez JA, Esguevillas G, Amo G, Garcia-Martin E. Pharmacogenomics testing for type $B$ adverse drug reactions to anti-infective drugs: the example of hypersensitivity to abacavir. Recent Pat Antiinfect Drug Discov. 2014;9(2):151.

78. Szczeklik A, Nizankowska E, Duplaga M. Natural history of aspirin-induced asthma. AIANE Investigators. European Network on Aspirin-Induced Asthma. Eur Res J. 2000;16(3):432-6.

79. Caimmi SM, Manca E, Caimmi D, Marseglia GL, Demoly P. NSAID hypersensitivity in twins. Pediatr Allergy Immunol. 2014;25(8):828-9.

80. Mastalerz L, Setkowicz M, Sanak M, Rybarczyk H, Szczeklik A. Familial aggregation of aspirin-induced urticaria and leukotriene $\mathrm{C}$ synthase allelic variant. $\mathrm{Br} J$ Dermatol. 2006;154(2):256-60.

81. Cornejo-Garcia JA, Jagemann LR, Blanca-Lopez $N$, Dona I, Flores C, Gueant-Rodriguez RM, Torres MJ, Fernández J, Laguna JJ, Rosado A, Agúndez JA, García-Martín E, Canto G, Guéant JL, Blanca M. Genetic variants of the arachidonic acid pathway in non-steroidal anti-inflammatory drug-induced acute urticaria. Clin Exp Allergy. 2012;42(12):1772-81.

82. Vidal C, Porras-Hurtado L, Cruz R, Quiralte J, Cardona V, Colas C, Castillo LF, Marcos C, Soto T, Lopez-Abad R, Hernández D, Audicana MT, Armisén M, Rodríguez V, Perez-Carral C, Moreno $E$, Cabañes $R$, Corominas M, Parra A, Lobera T, Quiñones D, Ojeda P, Luna I, Torres M, Carracedo A. Association of thromboxane $\mathrm{A} 1$ synthase (TBXAS1) gene polymorphism with acute urticaria induced by nonsteroidal anti-inflammatory drugs. J Allergy Clin Immunol. 2013;132(4):989-91.

83. Cornejo-Garcia JA, Flores C, Plaza-Seron MC, Acosta-Herrera M, Blanca-Lopez N, Doña I, Torres MJ, Mayorga C, GuéantRodríguez RM, Ayuso P, Fernández J, Laguna JJ, Agúndez JA, García-Martín E, Guéant JL, Canto G, Blanca M. Variants of CEP68 gene are associated with acute urticaria/angioedema induced by multiple non-steroidal anti-inflammatory drugs. PloS one. 2014;9(3):e90966. 
84. Kowalski ML, Woessner K, Sanak M. Approaches to the diagnosis and management of patients with a history of nonsteroidal anti-inflammatory drug-related urticaria and angioedema. J Allergy Clin Immunol. 2015;136(2):245-51.

85. Kim SH, Sanak M, Park HS. Genetics of hypersensitivity to aspirin and nonsteroidal anti-inflammatory drugs. Immunol Allergy Clin North Am. 2013;33(2):177-94.

86. Shrestha Palikhe N, Kim SH, Jin HJ, Hwang EK, Nam YH, Park HS. Genetic mechanisms in aspirin-exacerbated respiratory disease. J Allergy. 2012;2012:794890.

87. Gueant JL, Gueant-Rodriguez RM, Gastin IA, Cornejo-Garcia JA, Viola M, Barbaud A, Mertes PM, Blanca M, Romano A. Pharmacogenetic determinants of immediate and delayed reactions of drug hypersensitivity. Curr Pharm Des. 2008;14(27):2770-7.

88. Garcia-Martin E, Ayuso P, Martinez C, Blanca M, Agundez JA. Histamine pharmacogenomics. Pharmacogenomics. 2009; 10(5):867-83.

89. Kim SH, Kang YM, Kim SH, Cho BY, Ye YM, Hur GY, Park HS. Histamine N-methyltransferase 939A $>$ G polymorphism affects mRNA stability in patients with acetylsalicylic acidintolerant chronic urticaria. Allergy. 2009;64(2):213-21.

90. Ayuso P, Blanca M, Cornejo-Garcia JA, Torres MJ, Doña I, Salas M, Blanca-López N, Canto G, Rondón C, Campo P, Laguna JJ, Fernández J, Martínez C, Agúndez JA, GarcíaMartín E. Variability in histamine receptor genes HRH1, $\mathrm{HRH} 2$ and HRH4 in patients with hypersensitivity to NSAIDs. Pharmacogenomics. 2013;14(15):1871-8.

91. Agundez JA, Ayuso P, Cornejo-Garcia JA, Blanca M, Torres MJ, Dona I, Salas M, Blanca-López N, Canto G, Rondon C, Campo P, Laguna JJ, Fernández J, Martínez C, García-Martín E. The diamine oxidase gene is associated with hypersensitivity response to non-steroidal anti-inflammatory drugs. PLoS One. 2012;7(11):e47571.

92. Kim SH1, Nam EJ, Kim YK, Ye YM, Park HS. Functional variability of the adenosine $A 3$ receptor (ADORA3) gene polymorphism in aspirin-induced urticaria. Br J Dermatol. 2010;163(5):977-85.

93. Kim BS, Park SM, Uhm TG, Kang JH, Park JS, Jang AS, Uh ST, Kim MK, Choi IS, Cho SH, Hong CS, Lee YW, Lee JY, Choi BW, Park HS, Park BL, Shin HD, Chung IY, Park CS. Effect of single nucleotide polymorphisms within the interleukin-4 promoter on aspirin intolerance in asthmatics and interleukin-4 promoter activity. Pharmacogenet Genomics. 2010;20(12):748-58.

94. Dekker JW, Nizankowska E, Schmitz-Schumann M, Pile K, Bochenek G, Dyczek A, Cookson WO, Szczeklik A. Aspirininduced asthma and HLA-DRB1 and HLA-DPB1 genotypes. Clin Exp Allergy. 1997;27(5):574-7.

95. Choi JH, Lee KW, Oh HB, Lee KJ, Suh YJ, Park CS, Park HS. HLA association in aspirin-intolerant asthma: DPB1*0301 as a strong marker in a Korean population. J Allergy Clin Immunol. 2004;113(3):562-4.

96. Kim SH, Choi JH, Lee KW, Kim SH, Shin ES, Oh HB, Suh $\mathrm{CH}, \mathrm{Nahm} \mathrm{DH}$, Park HS. The human leucocyte antigenDRB1*1302-DQB1*0609-DPB1*0201 haplotype may be a strong genetic marker for aspirin-induced urticaria. Clin Exp Allergy. 2005;35(3):339-44.

97. Ayuso P, Plaza-Seron Mdel C, Dona I, Blanca-Lopez N, Campo P, Cornejo-Garcia JA, Perkins JR, Torres MJ, Blanca M, Canto $\mathrm{G}$. Association study of genetic variants in PLA2G4A, PLCG1,
LAT, SYK, and TNFRS11A genes in NSAIDs-induced urticaria and/or angioedema patients. Pharmacogenet Genomics. 2015;25(12):618-21.

98. Garcia-Martin E, Esguevillas G, Blanca-Lopez N, GarciaMenaya J, Blanca M, Amo G, Canto G, Martínez C, Cordobés C, Agúndez JA. Genetic determinants of metamizole metabolism modify the risk of developing anaphylaxis. Pharmacogenet Genomics. 2015;25(9):462-4.

99. Gomez F, Perkins JR, Garcia-Martin E, Canto G, Cornejo-Garcia JA. Genetic basis of hypersensitivity reactions to nonsteroidal anti-inflammatory drugs. Curr Opin Allergy Clin Immunol. 2015;15(4):285-93.

100. Kim JH, Park BL, Cheong HS, Bae JS, Park JS, Jang AS, Uh ST, Choi JS, Kim YH, Kim MK, Choi IS, Cho SH, Choi BW, Park CS, Shin HD. Genome-wide and follow-up studies identify CEP68 gene variants associated with risk of aspirin-intolerant asthma. PLoS One. 2010;5(11):e13818.

101. Park BL, Kim TH, Kim JH, Bae JS, Pasaje CF, Cheong HS, Kim LH, Park JS, Lee HS, Kim MS, Choi IS, Choi BW, Kim MK, Shin S, Shin HD, Park CS. Genome-wide association study of aspirinexacerbated respiratory disease in a Korean population. Hum Genet. 2013;132(3):313-21.

102. Cornejo-Garcia JA, Liou LB, Blanca-Lopez N, Dona I, Chen CH, Chou YC, Chuang HP, Wu JY, Chen YT, Plaza-Serón Mdel C, Mayorga C, Guéant-Rodríguez RM, Lin SC, Torres MJ, Campo P, Rondón C, Laguna JJ, Fernández J, Guéant JL, Canto G, Blanca M, Lee MT. Genome-wide association study in NSAID-induced acute urticaria/angioedema in Spanish and Han Chinese populations. Pharmacogenomics. 2013;14(15):1857-69.

103. Sanak M, Pierzchalska M, Bazan-Socha S, Szczeklik A. Enhanced expression of the leukotriene $C(4)$ synthase due to overactive transcription of an allelic variant associated with aspirin-intolerant asthma. Am J Respir Cell Mol Biol. 2000;23(3):290-6. PubMed PMID: 10970818.

104. Sampson AP, Cowburn AS, Sladek K, Adamek L, Nizankowska E, Szczeklik A, Lam BK, Penrose JF, Austen KF, Holgate ST. Profound overexpression of leukotriene C4 synthase in bronchial biopsies from aspirin-intolerant asthmatic patients. Int Arch Allergy Immunol. 1997;113(1-3):355-7.

105. Cowburn AS, Sladek K, Soja J, Adamek L, Nizankowska E, Szczeklik A, Lam BK, Penrose JF, Austen FK, Holgate ST, Sampson AP. Overexpression of leukotriene C4 synthase in bronchial biopsies from patients with aspirin-intolerant asthma. J Clin Invest. 1998:101(4):834-46.

106. Van Sambeek R, Stevenson DD, Baldasaro M, Lam BK, Zhao J, Yoshida S, Yandora C, Drazen JM, Penrose JF. 5' flanking region polymorphism of the gene encoding leukotriene $\mathrm{C} 4$ synthase does not correlate with the aspirin-intolerant asthma phenotype in the United States. J Allergy Clin Immunol. 2000;106(1 Pt 1):72-6.

107. Kawagishi Y, Mita H, Taniguchi M, Maruyama M, Oosaki R, Higashi N, Kashii T, Kobayashi M, Akiyama K. Leukotriene C4 synthase promoter polymorphism in Japanese patients with aspirin-induced asthma. J Allergy Clin Immunol. 2002;109(6):936-42.

108. Choi JH, Park HS, Oh HB, Lee JH, Suh YJ, Park CS, Shin HD. Leukotriene-related gene polymorphisms in ASA-intolerant asthma: an association with a haplotype of 5-lipoxygenase. Hum Genet. 2004;114(4):337-44. 
109. Mastalerz L, Setkowicz M, Sanak M, SzczeklikA. Hypersensitivity to aspirin: common eicosanoid alterations in urticaria and asthma. J Allergy Clin Immunol. 2004;113(4):771-5.

110. Torres-Galvan MJ, Ortega N, Sanchez-Garcia F, Blanco C, Carrillo T, Quiralte J. LTC4-synthase A-444C polymorphism: lack of association with NSAID-induced isolated periorbital angioedema in a Spanish population. Ann Allergy Asthma Immunol. 2001;87(6):506-10.

111. Ayuso P, Plaza-Seron Mdel C, Blanca-Lopez N, Dona I, Campo P, Canto G, Laguna JJ, Bartra J, Soriano-Gomis V, Blanca M, Cornejo-García JA, Perkins JR. Genetic variants in arachidonic acid pathway genes associated with NSAIDexacerbated respiratory disease. Pharmacogenomics. 2015;16(8):825-39.

112. Lee HY, Kim SH, Ye YM, Choi GS, Park HS. Lack of association of ALOX12 and ALOX15 polymorphisms with aspirinexacerbated respiratory disease in Korean patients. Ann Allergy Asthma Immunol. 2009;103(1):84-6.

113. Oh SH, Kim YH, Park SM, Cho SH, Park JS, Jang AS, Park SW, Uh ST, Lee YM, Kim MK, Choi IS, Cho SH, Hong CS, Lee YW, Lee JY, Choi BW, Park BL, Shin HD, Park CS. Association analysis of thromboxane $A$ synthase 1 gene polymorphisms with aspirin intolerance in asthmatic patients. Pharmacogenomics. 2011;12(3):351-63.

114. Honda T, Kabashima K. Prostanoids in allergy. Allergol Int. 2015;64(1):11-6.

115. Kim SH, Kim YK, Park HW, Jee YK, Kim SH, Bahn JW, Chang YS, Kim SH, Ye YM, Shin ES, Lee JE, Park HS, Min KU. Association between polymorphisms in prostanoid receptor genes and aspirin-intolerant asthma. Pharmacogenet Genomics. 2007:17(4):295-304

116. Park BL, Park SM, Park JS, Uh ST, Choi JS, Kim YH, Kim MK, Choi IS, Choi BW, Cho SH, Hong CS, Lee YW, Lee JY, Park CS, Shin HD. Association of PTGER gene family polymorphisms with aspirin intolerant asthma in Korean asthmatics. BMB Rep. 2010;43(6):445-9.

117. Palikhe NS, Sin HJ, Kim SH, Sin HJ, Hwang EK, Ye YM, Park HS. Genetic variability of prostaglandin E2 receptor subtype EP4 gene in aspirin-intolerant chronic urticaria. J Hum Genet. 2012;57(8):494-9.

118. Oguma T, Palmer LJ, Birben E, Sonna LA, Asano K, Lilly CM. Role of prostanoid DP receptor variants in susceptibility to asthma. N Eng J Med. 2004;351(17):1752-63.

119. Kim SH, Oh JM, Kim YS, Palmer LJ, Suh CH, Nahm DH, Park HS. Cysteinyl leukotriene receptor 1 promoter polymorphism is associated with aspirin-intolerant asthma in males. Clin Exp Allergy. 2006;36(4):433-9.

120. Arriba-Mendez S, Sanz C, Isidoro-Garcia M, Pascual M, Avila C, Davila I, Lorente F. Analysis of 927T > C CYSLTR1 and -444A $>$ C LTC4S polymorphisms in children with asthma. Allergol Immunopathol (Madr). 2008;36(5):259-63.

121. Hong X, Zhou H, Tsai HJ, Wang X, Liu X, Wang B, Liu X, Wang $B, X u X, X u X$. Cysteinyl leukotriene receptor 1 gene variation and risk of asthma. Eur Resp J. 2009;33(1):42-8.

122. Arriba-Mendez S, Sanz C, Isidoro-Garcia M, Davild I, Laffond E, Horeno E, Avila C, Lorente F. 927T $>$ C polymorphism of the cysteinyl-leukotriene type-1 receptor (CYSLTR1) gene in children with asthma and atopic dermatitis. Pediatr Allergy Immunol. 2006;17(5):323-8.
123. Bizzintino JA, Khoo SK, Zhang G, Martin AC, Rueter $K$, Geelhoed GC, Goldblatt J, Laing IA, Le Souëf PN, Hayden CM. Leukotriene pathway polymorphisms are associated with altered cysteinyl leukotriene production in children with acute asthma. Prostaglandins Leukot Essent Fatty Acids. 2009;81(1):9-15.

124. Park JS, Chang HS, Park CS, Lee JH, Lee YM, Choi JH, Shin HD. Association analysis of cysteinyl-leukotriene receptor 2 (CYSLTR2) polymorphisms with aspirin intolerance in asthmatics. Pharmacogenet Genomics. 2005;15(7):483-92.

125. Palikhe NS, Kim SH, Lee HY, Kim JH, Ye YM, Park HS. Association of thromboxane $A 2$ receptor (TBXA2R) gene polymorphism in patients with aspirin-intolerant acute urticaria. Clin Exp Allergy. 2011;41(2):179-85.

126. Kohyama K, Hashimoto $M$, Abe $S$, Kodaira $K$, Yukawa $T$, Hozawa S, Morioka J, Inamura H, Yano M, Ota M, Sagara $\mathrm{H}$, Kurosawa M. Thromboxane A2 receptor $+795 \mathrm{~T}>\mathrm{C}$ and chemoattractant receptor-homologous molecule expressed on Th2 cells -466T >C gene polymorphisms in patients with aspirin-exacerbated respiratory disease. Mol Med Rep. 2012;5(2):477-82

127. Kim SH, Cho BY, Choi H, Shin ES, Ye YM, Lee JE, Park HS. The SNP rs3128965 of HLA-DPB1 as a genetic marker of the AERD phenotype. PloS One. 2014;9(12):e111220.

128. Cornejo-Garcia JA, Mayorga C, Torres MJ, Fernandez TD, R-Pena R, Bravo I, Mates JM, Blanca M. Anti-oxidant enzyme activities and expression and oxidative damage in patients with non-immediate reactions to drugs. Clin Exp Immunol. 2006;145(2):287-95.

129. Cornejo-Garcia JA, Fernandez TD, Torres MJ, Carballo M, Hernan I, Antunez C, Blanca M, Mayorga C. Differential cytokine and transcription factor expression in patients with allergic reactions to drugs. Allergy. 2007;62(12):1429-38.

130. Fernandez TD, Mayorga C, Torres MJ, Cornejo-Garcia JA, Lopez S, Chaves P, Rondon C, Blanca M. Cytokine and chemokine expression in the skin from patients with maculopapular exanthema to drugs. Allergy. 2008;63(6):712-9.

131. Morel E, Alvarez L, Cabanas R, Fiandor A, Diaz R, Escamochero S, Prior N, Blanca M, Bellón T. Expression of alpha-defensin 1-3 in T cells from severe cutaneous drug-induced hypersensitivity reactions. Allergy. 2011;66(3):360-7.

132. FernandezTD, Mayorga C, Gueant JL, Blanca M, Cornejo-Garcia JA. Contributions of pharmacogenetics and transcriptomics to the understanding of the hypersensitivity drug reactions. Allergy. 2014;69(2):150-8.

133. Cheong HS, Park SM, Kim MO, Park JS, Lee JY, Byun JY, Park $B L$, Shin HD, Park CS. Genome-wide methylation profile of nasal polyps: relation to aspirin hypersensitivity in asthmatics. Allergy. 2011;66(5):637-44.

134. Shin S, Park JS, Kim YJ, Oh T, An S, Park CS. Differential gene expression profile in PBMCs from subjects with AERD and ATA: a gene marker for AERD. Mol Genet Genomics. 2012;287(5):361-71.

135. Shin SW, Park BL, Chang H, Park JS, Bae DJ, Song HJ, Choi IS, Kim MK, Park HS, Kim LH, Namgoong S, Kim JO, Shin HD, Park CS. Exonic variants associated with development of aspirin exacerbated respiratory diseases. Plos One. 2014;9(11):e111887. 
136. Agundez JA, Gonzalez-Alvarez DL, Vega-Rodriguez MA, Botello E, Garcia-Martin E. Gene variants and haplotypes modifying transcription factor binding sites in the human cyclooxygenase 1 and 2 (PTGS1 and PTGS2) genes. Curr Drug Metab. 2014;15(2):182-95.

137. Agundez JA, Blanca M, Cornejo-Garcia JA, Garcia-Martin E. Pharmacogenomics of cyclooxygenases. Pharmacogenomics. 2015;16(5):501-22.

138. Perkins JR, Barrionuevo E, Ranea JA, Blanca M, CornejoGarcia JA. Systems biology approaches to enhance our understanding of drug hypersensitivity reactions. Clin Exp Allergy 2014;44(12):1461-72.

139. Perkins JR, Ayuso P, Cornejo-Garcia JA, Ranea JA. The study of severe cutaneous drug hypersensitivity reactions from a systems biology perspective. Curr Opin Allergy Clin Immunol 2014;14(4):301-6.

140. Perkins JR, Sanak M, Canto G, Blanca M, Cornejo-Garcia JA. Unravelling adverse reactions to NSAIDs using systems biology. Trends Pharmacol Sci. 2015;36(3):172-80.
Manuscript received February 9, 2016; accepted for publication May 11, 2016.

\section{- José A Cornejo-García}

Research Laboratory

IBIMA, Regional University Hospital of Malaga

Plaza del Hospital Civil s/n

Hospital Civil, Pabellón 6, $1^{\text {a }}$ planta

29009 Málaga, Spain

E-mail: josea.cornejo@ibima.eu 